\title{
Effect of Dip Time on the Structural and Optical Properties of Chemically Deposited CdSe Thin Films
}

\author{
R. A. Chikwenze ${ }^{2}$, P. A. Nwofe, ${ }^{1, ~ *}$, P. E. Agbo ${ }^{1}$, S. N. Nwankwo' ${ }^{1}$ J. E. Ekpe ${ }^{1}$, F. U. Nweke \\ ${ }^{1}$ Division of Materials Science and Renewable Energy, Department of Industrial Physics, Faculty of Sciences, Ebonyi State University, \\ Abakaliki, Nigeria \\ ${ }^{2}$ Department of Physics, Faculty of Natural Sciences, Federal University, Ndufu-Alike, Ikwo, Nigeria
}

Email address:

patricknwofe@gmail.com (P. A. Nwofe), ekumaagbo@gmail.com (P. E. Agbo), nwankwo.s.n@gmail.com (S. N. Nwankwo), racy_c@yahoo.com (R. A. Chikwenze),Sirekpe1@gmail.com (J. E. Ekpe), frinweke@yahoo.com (F. U. Nweke)

\section{To cite this article:}

R. A. Chikwenze, P. A. Nwofe, P. E. Agbo, S. N. Nwankwo, J. E. Ekpe, F. U. Nweke. Effect of Dip Time on the Structural and Optical Properties of Chemically Deposited CdSe Thin Films. International Journal of Materials Science and Applications.

Vol. 4, No. 2, 2015, pp. 101-106. doi: 10.11648/j.ijmsa.20150402.15

\begin{abstract}
In this study, the effect of dip time on the structural and optical properties of cadmium selenide (CdSe) thin films grown by the chemical bath deposition method is reported. The films were grown with varying dip time in the range of $4 \mathrm{~h}$ to $12 \mathrm{~h}$, and the other deposition variables (substrate temperature, source to substrate distance, $\mathrm{pH}$, and concentration) were kept constant. X-ray diffractometry (XRD) and optical spectroscopy were used to characterise the layers. The results show that the crystallite size and the film thickness increased with an increase in the dip time up to a "critical value" and then decreased otherwise for the latter. The increase in the crystallite size was more pronounced at the lower dip time $(<8 \mathrm{~h})$, and then exhibited a marginal increase for dip time $>8 \mathrm{~h}$. The energy band gap was found to be direct with an optimum value of $1.2 \mathrm{eV}$ obtained for films grown at a dip time of $8 \mathrm{~h}$.
\end{abstract}

Keywords: Dip Time, Film Thickness, Crystallite Size, Energy Bandgap

\section{Introduction}

Thin films has been universally accepted as the best way to make solar cell devices with increased solar conversion efficiency at reduced materials cost. Currently, the best thin film solar cells are those based on the use of the chalcopyrites- Copper indium gallium diselenides (CIGS) and Cadmium telluride (CdTe) based solar cells. Efficiencies $>10 \%$ have also been reported for kesterites solar cells [1]. Most recently, solar cells based on more environmentally acceptable with earth abundant materials such as tin sulphide $(\mathrm{SnS})$ have been developed, though at laboratory scale [2-6]. It has been established that Cadmium selenide is a direct band gap semiconductor belonging to the II-VI groups of semiconductor family [7-8]. CdSe is known to exhibit n-conductivity type both in the bulk and in thin film form independent of the deposition technique and this is usually associated to the native defects in the excess $\mathrm{Cd}$ and Se vacancies [9-12]. Cadmium selenide have been used in various optoelectronic applications such as in solar cells [13-14], and in other electronic and industrial applications which includes; $\gamma$-ray detector [15], thin film transistors [16-17], photoconductors [18-23], sensors [24-25], photonic devices [26-30], memory switching devices [31-34], acousto-optic reflector [35], hydrocarbon detectors [36] and in optical fibres [37-38]. Reports in the literature indicate that cadmium selenide can be grown by the use of different low cost and efficient technique such as; successive ionic layer and reaction (SILAR) [39-40], thermal evaporation [41-49], electron beam evaporation [50], chemical bath deposition [51-57], electro-deposition [58-61], Electrostatic assisted aerosol jet deposition [62], hot wall deposition [63-65], and spray pyrolysis [66-69].

Although several deposition techniques for growing high quality $\mathrm{CdSe}$ thin films exist in the literature, chemical bath deposition is more commonly used compared to the other deposition method because: (i) it is a low cost deposition technique (ii) the apparatus mostly used are common and less expensive (iii) it gives room for large area deposition (iv) it allows for more flexibility in device designs and (v) it is easier to tune the properties through appropriate manipulation of the deposition variables. In the present investigation, we employed the chemical bath deposition 
technique and report on the effect of dip time on the structural and optical properties of the layers.

\section{Materials and Methods}

\subsection{Substrate Preparation}

One of the initial fundamental steps needed to reduce the potential site for interface recombination in thin films is to ensure the use of clean substrates for deposition. In this study, sodalime glass slides with the dimensions: $76 \mathrm{~mm} \times 26 \mathrm{~mm}$, were used as substrates. The sodalime glasses were first cleaned using detergent and with distilled water. Further, the glass substrates were then cleaned ultrasonically for $15 \mathrm{~min}$, followed by a rinse with acetone and the glass substrates were then dried using nitrogen gas.

\subsection{Sample Preparation and CdSe Thin Film Formation}

The initial step was the preparation of a $1 \mathrm{M} \mathrm{CdCl}_{2}$ (cadmium chloride), 2M TEA (Tetraethylammonium), 3M $\mathrm{NH}_{4} \mathrm{OH}$ (ammonium hydroxide), and $\mathrm{IM} \mathrm{Na}_{2} \mathrm{SeSO}_{3}$ (sodium selenide trioxosulphate (vi)), with each of these solution put in a separate beaker. This was followed by the formation of a reaction bath made by measuring $7.5 \mathrm{ml}$ of the solutions each $\left(\mathrm{CdCl}_{2}, \mathrm{NH}_{4} \mathrm{OH}\right.$ and $\left.\mathrm{Na}_{2} \mathrm{SeSO}_{3}\right)$ and $10 \mathrm{ml}$ of TEA. The reaction bath was a graduated $100 \mathrm{ml}$ beaker. The sodalime glass slides were carefully labeled and then dipped into the solution. The dip time was in the range $4 \mathrm{~h}$ to $12 \mathrm{~h}$. The sodalime glasses were removed from each of the reaction baths at intervals of; $4 \mathrm{~h}, 6 \mathrm{~h}, 8 \mathrm{~h}$ and $12 \mathrm{~h}$ respectively. The films were then washed thoroughly with distilled water and then dried.

The as-grown films were characterised structurally, using the Philips PW 1500 XRD. The morphological and compositional characterization was done using an optical microscope (KPL-W10x/18 Zeiss Standard 14 photomicroscope with $\mathrm{M}_{35}$ $4760+2-9901$ camera at a magnification of X200) and RBS (Rutherford Back Scattering) technique. The optical characterisation was done with a Unico-UV-2102PC spectrophotometer and the wavelength range was between 200 $\mathrm{nm}$ to $1200 \mathrm{~nm}$. The film thickness was measured using the gravimetric method.

\section{Results and Discussion}

\subsection{Morphological and Compositional Analysis}

Physical observation of the as-grown layers indicates a yellowish brown colour. Figure 1 gives a typical photomicrography of the as-deposited layers. The films grown at a dip time of $8 \mathrm{~h}$ showed large densely populated nano-size grains with multiple leaf-like clusters. The average grain sizes of the films deduced from the photomicrography measurement is $0.32 \mathrm{~nm}$ for the films deposited for a dip time $8 \mathrm{~h}$. The composition of the films as obtained from the RBS studies show that the major constituents are $\mathrm{Cd}$ and $\mathrm{Se}$ with significant proportion of oxygen. Other elements arising from the substrate used were also observed as in indicated in Table 1. The presence of oxygen in the films could be attributed to the effect of surface interaction with atmospheric oxygen during film growth. Other research groups have reported on the presence of oxygen in CdSe thin films independent of the deposition technique [70].

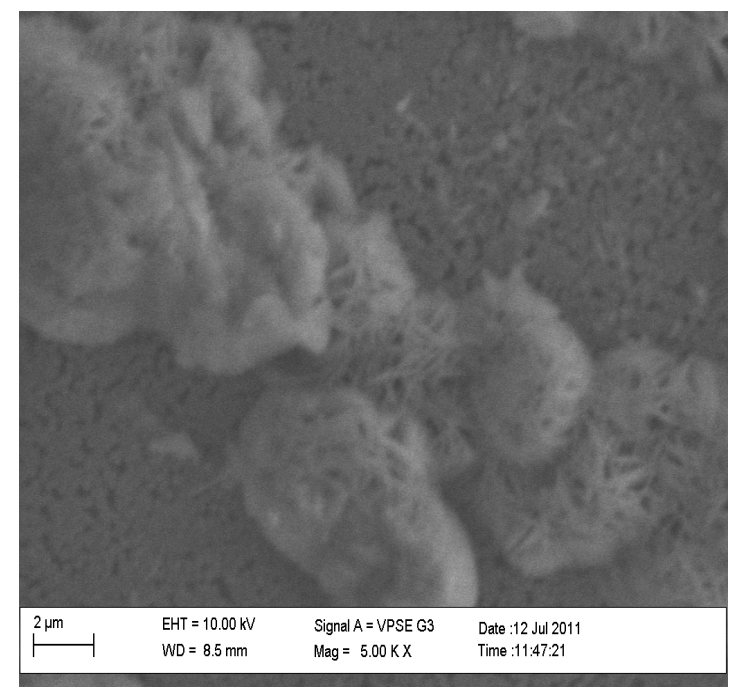

Figure 1. Typical photomicrography of CdSe thin film at dip time of $8 \mathrm{~h}$.

\subsection{Structural Analysis}

The structural studies was done using the data extracted from the XRD diffractogram (not shown). The crystallite size was deduced using the Scherer's formula given as [71-73];

$$
\mathrm{D}=\frac{0.94 \lambda}{\beta \cos \theta}
$$

In equation (1), $\mathrm{D}$ is the crystallites size, $\lambda$ is the wavelength of the $\mathrm{CuK} \alpha$ radiation source given as $(\lambda=0.15406 \mathrm{~nm}), \beta$ is the full width at half maximum of the most prominent peak and $\theta$ is the Bragg angle. Figure 2 gives the variation of the crystallites size with dip time. As indicated in Figure 2, the crystallites size increased with an increase in the dip time. From Figure 2, it is observed that the increase was more marginal for deposition time $>8 \mathrm{~h}$ and more pronounced for dip time $<8 \mathrm{~h}$. This behavior could be explained on the basis that with the increase in the dip time, the crystallites size increased due to decrease in the surface mobility of the films thereby enabling the films to decrease its total energy by growing larger grains. Variation of the crystallites/grain size of CdSe thin film has been reported in the literature by various authors. Velumani et al [63], made similar observation (increase in crystallite size with film thickness) for cadmium selenide thin films grown by the hot wall deposition technique on different substrates and noted that this was due to the formation of new smaller grains on the larger grains. The behavior exhibited for dip time $>8 \mathrm{~h}$ is similar to the reported by other research groups for evaporated CdSe layers [47]. In this study, the trend exhibited in this range $(>8 \mathrm{~h})$ is attributed to the fragmentation of the crystallites due to the longer dip 
time and/or the difference in the vapour pressures of cadmium and selenium respectively.

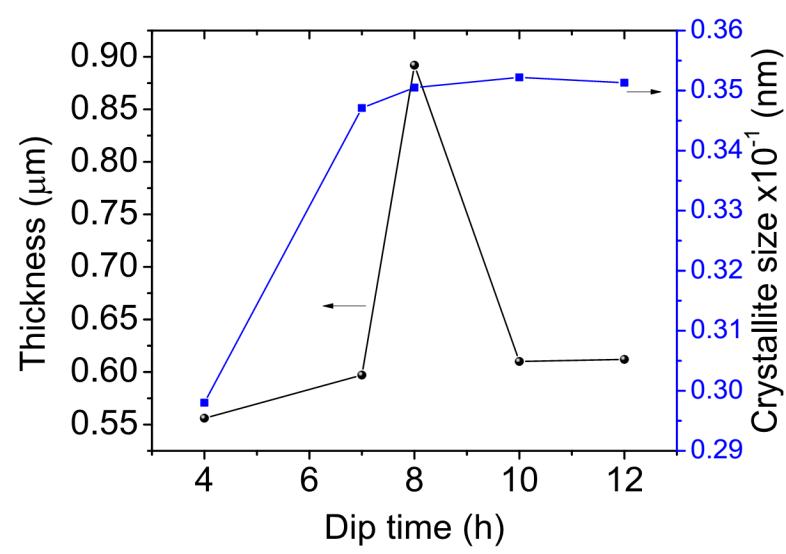

Figure 2. Variation of crystallites size, and thickness with the dip time.

\subsection{Optical Analysis}

The optical caracterisation was done as indicated earlier (experimental section) with the transmittance and absorbance measurement in the range $400 \mathrm{~nm}$ to $1200 \mathrm{~nm}$. From the absorbance and transimatance versus wavelength measurements the energy bandgap of the layers were deduced. The energy band gap was calculated using the relation [74-76];

$$
\alpha=B\left(h v-E_{g}\right)^{n}
$$

In this formula, $\mathrm{B}$ is an energy independent constant, $\mathrm{E}_{\mathrm{g}}$ is the energy bandgap and the exponent $n=1 / 2$ for direct allowed transition and 3/2 for indirect allowed transition [74]. Figure 3 gives the variation of the energy bandgap with the dip time. The value of the energy bandgap was in the range 0.98 $\mathrm{eV}$ to $1.24 \mathrm{eV}$. The value of the energy band gap obtained in this study is within the range reported by other authors [77].

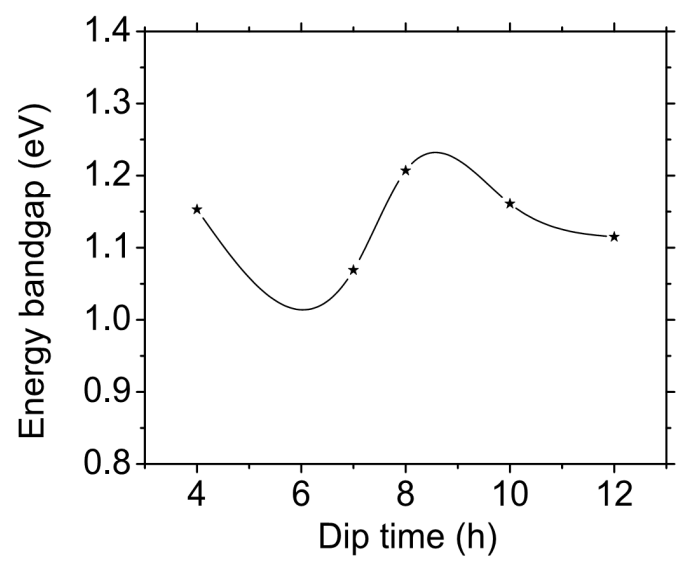

Figure 3. Variation of energy bandgap with dip time.

\section{Conclusions}

CdSe thin films has been grown by the dip technique and the results of the structural and optical properties is reported.
Results exhibited by the structural studies indicate that the crystallites size increased with an increase in the dip time up to a critical dip time of $8 \mathrm{~h}$ and then exhibited a marginal increase thereafter. The energy bandgap was between $0.98 \mathrm{eV}$ to 1.24 eV. The energy bandgap obtained in this study strongly suggest the possible use of the layers as infrared detectors and absorber layers in solar cell devices.

Table 1. Composition of an as-grown CdSe layer grown at a dip time of $8 \mathrm{~h}$.

\begin{tabular}{llllllll}
\hline Elements & $\mathbf{C d}$ & $\mathbf{S e}$ & $\mathbf{O}$ & $\mathbf{S i}$ & $\mathbf{C a}$ & $\mathbf{A l}$ & $\mathbf{N a}$ \\
\hline Composition & & & & & & & \\
& 0.120 & 0.250 & 0.630 & & & & \\
& & & 0.520 & 0.120 & 0.050 & 0.130 & 0.180 \\
\hline
\end{tabular}

\section{Acknowledgements}

One of the authors, Dr R.A. Chikwenze would like to thank the staff of the Centre for Energy Research and Development, Obafemi Awolowo University, Ile-Ife for the Rutherford Backscattering Measurements.

\section{References}

[1] D. Aaron, R. Barkhouse, O. Gunawan, T. Gokmen, T.K. Todorov and D. B. Mitzi, "Device Characterisation of a $10.1 \%$ hydrazine-processed $\mathrm{Cu}_{2} \mathrm{ZnSn}(\mathrm{Se}, \mathrm{S})_{4}$ solar cell," Prog. Photovotaic. Res. Appl., vol. 20, pp. 6-11, 2012.

[2] P.A. Nwofe, K.T. Ramakrishna Reddy and R.W. Miles "Effects of sulphur and air annealing on the properties of thermally evaporated SnS layers for application in thin film solar cell devices" J. Renewable \& Sustainable Energy, Vol. 5, pp. 011024, 2013.

[3] P.A. Nwofe, K.T. Ramakrishna Reddy and R.W. Miles "Determination of the Minority Carrier Diffusion Length of SnS Using Electro-optical Measurements" Electron Mater Letts, Vol. 9(3), pp. 363-366, 2013.

[4] P.A. Nwofe, (2013). Deposition and Characterisation of SnS Thin Films for Application in Photovoltaic Solar Cell Devices, Ph.D Thesis, Northumbria University, United Kingdom

[5] P. Sinsermsuksakul, L. Sun, S. Woon Lee, H. Hejin Park, S. Bok Kim, C. Yang and R. G. Gordon, "Overcoming efficiency limitations in SnS-based solar cells", Advanced Energy Materials, vol. 4(15) pp. 1400496, 2014.

[6] K. Hartman (2013). Proceedings of the Materials Research Society. Accessed January 3, 2015 at: www.mrs.org/fall-2013-meeting-scene-day-4/.

[7] A. L. Fahrenbruch, R. H. Bube, Fundamentals of Solar Cells: Photovoltaic Solar Energy Conversion, Academic Press, New York (1983).

[8] S.M. Sze, Semiconductor Devices Physics and Technology, John Wiley \& Sons, New York, 1985.

[9] A.O. Oduor and R. D. Gould. "Space-charge-limited conductivity in evaporated cadmium selenide thin films", Thin Solid Films, vol. 270, pp. 387-390, 1995. 
[10] A.O. Oduor and R. D. Gould. "A comparison of the DC conduction properties in evaporated cadmium selenide thin films using gold and aluminium electrodes", Thin Solid Films, vol. 317, pp. 409-412, 1998.

[11] D. Nesheva, D. Arsova, and R. Ionov. "Thin and superthin photoconductive CdSe films deposited at room substrate temperature", Journal of materials science, vol. 28, pp. 2183-2186, 1993.

[12] F. Raoult, B. Fortin, and Y. Colin, "Standardization and stabilization of the resistivity-temperature characteristics of CdSe thin films by vacuum annealing", Thin Solid Films, vol. 182 pp. 1-14, 1989.

[13] H. Richter, 20th IEEE photovoltaics specialists conf., New York, pp. 1537, 1988.

[14] A.K. Pal, A. Mondal, and S. Chaudhuri. "Preparation and characterization of $\mathrm{ZnTe} / \mathrm{CdSe}$ solar cells", Vacuum, vol. 41, pp. 1460-1462, 1990.

[15] M. Roth, "Advantages of limitations of Cadmium Selenide room temperature gamma ray detectors" Nucl. Instrum. Methods UK, vol. A283, pp. 291, 1989.

[16] J. Levinson, F.R. Shepherd, P.J. Scanlon, W.D. Westwood, G. Este, and M. Rider, "Conductivity behavior in polycrystalline semiconductor thin film transistors", Journal of Applied Physics, vol. 53(2), pp. 1193-1202, 1982.

[17] F.Y. Gan and I. Shih, "Preparation of thin-film transistors with chemical bath deposited CdSe and CdS thin films", Electron Devices, IEEE Transactions on, vol. 49, pp. 15-18, 2002.

[18] J.S. Skarman, "On the relationship between photocurrent decay time and trap distribution in CdS and CdSe photoconductors", Solid-State Electronics, vol. 8, pp. 17-29, 1965.

[19] P. Pargas, "Phenomena of image sharpness recognition of CdS and CdSe photoconductors", JOSA, vol. 54, pp. 516-517, 1964.

[20] D.J. Pena, J.K. Mbindyo, A.J. Carado, T.E. Mallouk, C.D. Keating, B. Razavi and T.S Mayer, Template growth of photoconductive metal-CdSe-metal nanowires. The Journal of Physical Chemistry B, vol. 106, pp. 7458-7462, 2002.

[21] N.E. Coates, H. Zhou, S. Krämer, L. Li, and D. Moses, "Solution-Based In Situ Synthesis and Fabrication of Ultrasensitive CdSe Photoconductors", Advanced Materials, vol. 22 , pp. 5366-5369, 2010.

[22] T. Elango, V. Subramanian, and K.R. Murali, "Characteristics of spray-deposited CdSe thin films", Surface and Coatings Technology, vol. 123, pp. 8-11, 2000.

[23] E. Talgorn, E. Moysidou, R.D. Abellon, T.J. Savenije, A. Goossens, A.J. Houtepen and L.D. Siebbeles, "Highly photoconductive CdSe quantum-dot films: influence of capping molecules and film preparation procedure" The Journal of Physical Chemistry C, vol. 114, pp. 3441-3447, 2010 .

[24] S.S. Joshi, C.D. Lokhande and S.H. Han, "A room temperature liquefied petroleum gas sensor based on all-electrodeposited n-CdSe/p-polyaniline junction" Sensors and Actuators B: Chemical, vol. 123, pp. 240-245, 2007.

[25] V.A. Smyntyna, V. Gerasutenko, S. Kashulis, G. Mattongo, S. Reghini, "The causes of thickness dependence on the sensitivity of CdSe and CdS gas sensors to oxygen" Sensors Actuators B, vol.19, pp. 464-465, 1994.
[26] G.V. Prakash, R. Singh, A. Kumar and R.K. Mishra, "Fabrication and characterisation of CdSe photonic structures from self-assembled templates" Materials Letters, vol. 60, pp. 1744-1747, 2006..

[27] I.B. Divliansky, A. Shishido, I.C. Khoo, T.S. Mayer, D. Pena, S Nishimura and T.E. Mallouk, "Fabrication of two-dimensional photonic crystals using interference lithography and electrodeposition of CdSe" Applied Physics Letters, vol. 79, pp. 3392-3394, 2001.

[28] K. Kalyanasundaram and M. Grätzel, "Applications of functionalized transition metal complexes in photonic and optoelectronic devices", Coordination chemistry reviews, vol. 177, pp. 347-414, 1998.

[29] Y. Li, F. Qian, J. Xiang and C.M. Lieber, "Nanowire electronic and optoelectronic devices", Materials Today, vol. 9, pp. 18-27, 2006.

[30] J.Y. Kim and F.E. Osterloh, "ZnO-CdSe nanoparticle clusters as directional photoemitters with tunable wavelength", Journal of the American Chemical Society, vol. 127, pp. 10152-10153, 2005.

[31] C.R. Baxter and W.D. McLennan, "Organic type switching in tin selenide thin films", J. Vac. Sci. Technol. Vol. 12, pp. 110, 1975.

[32] M.D. Fischbein and M. Drndic, "CdSe nanocrystal quantum-dot memory", Applied Physics Letters, vol. 86, pp. 193106, 2005.

[33] S. Sahu, S.K. Majee, A.J. Pal, "Layer-by-layer assembly of capped CdSe nanoparticles: electrical bistability and memory phenomenon", Applied Physics Letters, vol. 91, pp. 143108, 2007.

[34] F. Li, D.I. Son, J.H. Ham, B.J. Kim, J.H. Jung, T.W. Kim, "Memory effect of nonvolatile bistable devices based on $\mathrm{CdSe} / \mathrm{ZnS}$ nanoparticles sandwiched between C 60 layers", Applied Physics Letters, vol. 91, pp. 162109-162109, 2007.

[35] B. Bonello, and B. Fernandez, "Elastic constants of CdSe at low temperature", Journal of Physics and Chemistry of Solids, vol. 54, pp. 209-212, 1993.

[36] O.V. Vassiltsova, Z. Zhao, M.A. Petrukhina, M.A. Carpenter, "Surface-functionalized CdSe quantum dots for the detection of hydrocarbons", Sensors and Actuators B: Chemical, vol.123, pp. 522-529, 2007.

[37] C.S. Chu, and C.Y. Chuang, "Optical fiber sensor for dual sensing of dissolved oxygen and $\mathrm{Cu} 2+$ ions based on PdTFPP/CdSe embedded in sol-gel matrix", Sensors and Actuators B: Chemical, vol. 209, pp. 94-99, 2015.

[38] L. Ding, C. Fan, Y. Zhong, T. Li, and J. Huang, "A sensitive optic fiber sensor based on CdSe QDs fluorophore for nitric oxide detection", Sensors and Actuators B: Chemical, vol.185, pp.70-76, 2013.

[39] R.B. Kale, S.D. Sartale, B.K. Chougule and C.D. Lokhande, "Growth and characterisation of nanocrystalline CdSe thin films deposited by the successive ionic layer adsorption and reaction method", Semicond. Sci .Tech., UK, vol. 19, pp. 980, 2004.

[40] H.M. Pathan, B.R. Sankapal, J.D. Desai and C.D. Lokhande, "Preparation and characterization of nanocrystalline CdSe thin films deposited by SILAR method" Mater. Chem. \& Phys., vol. 78, pp. 11-14, 2002. 
[41] D. Pathinettam Padiyan, A. Marikani and K.R. Murali. "Influence of thickness and substrate temperature on electrical and photoelectrical properties of vacuum-deposited CdSe thin films", Mater. Chem. \& Phys., vol. 78, pp. 51-58, 2003.

[42] K.R. PRADIP KALITA, B. K. SARMA and H.L. DAS, "Space charge limited conduction in CdSe thin films", Bull. Mater. Sci., vol. 26, pp. 613-617, 2003.

[43] C. Baban, G.I. Rusu, "On the structural and optical characteristics of CdSe thin films" Appl. Surf. Sci, vol. 211, pp. 6-12, 2003.

[44] C. Baban, G. I. Rusu, P. Prepelita, "ON THE OPTICAL PROPERTIES OF POLYCRYSTALLINE CdSe THIN FILMS" Journal of Optoelectronics and Advanced Materials, Romania, Vol. 7, pp. 817 - 821, 2005.

[45] K. Subba Ramaiah, Y.K. Su, S.J. Chang, F.S. Juang, K. Ohdaira, Y. Shiraki, H.P. Liu, I.G. Chen, A.K. Bhatnagar, "Characterization of $\mathrm{Cu}$ doped $\mathrm{CdSe}$ thin films grown by vacuum evaporation" Journal of Crystal Growth 224 (2001) $74-82$

[46] D. Patidar, K. S. Rathore, N. S. Saxena, Kananbala Sharma, T. P. Sharma, "ENERGY BAND GAP AND CONDUCTIVITY MEASUREMENT OF CdSe THIN FILMS" Chalcogenide Letts. Vol. 5, pp. $21-25,2008$.

[47] U. Pal, D. Samanta, S. Ghorai, and A.K. Chaudhuri, "Optical constants of vacuum-evaporated polycrystalline cadmium selenide thin films", Journal of applied physics, vol. 74, pp. 6368-6374, 1993.

[48] R. Jäger-Waldau, N. Stücheli, M. Braun, M. Lux Steiner, E. Bucher, R. Tenne, H. Flaisher, W. Kerfin, R. Braun, and W. Koschel, "Thin-film CdSe: Photoluminescence and electronic measurements", Journal of applied physics, vol. 64, pp. 2601-2606, 1988 .

[49] M. Parlak, "Electrical, photo-electrical, optical and structural properties of CdSe thin films deposited by thermal and e-beam techniques", Journal of Physics D: Applied Physics, vol. 41, pp. 035405, 2008.

[50] N.S. Kissinger, M. Jayachandran, K. Perumal, C.S. Raja, "Structural and optical properties of electron beam evaporated CdSe thin films" Bull. Mater. Sci. vol. 30, pp. 547-551, 2007.

[51] R.B. Kale and C.D. Lokhande, "Systematic study on structural phase behavior of CdSe thin films", The Journal of Physical Chemistry B, vol. 109, pp. 20288-20294, 2005.

[52] R.B. Kale and C.D. Lokhande, "Band gap shift, structural characterization and phase transformation of CdSe thin films from nanocrystalline cubic to nanorod hexagonal on air annealing" Semicond. Sci.Tech., UK, vol. 20, pp. 1, 2005.

[53] S.S. Kale and C.D. Lokhande, "Thickness-dependent properties of chemically deposited CdSe thin films" Mater. Chem. \& Phys., vol. 62, pp. 103-108, 2000.

[54] M.T.S. Nair, P.K. Nair, R.A. Zingaro and E.A. Meyers, "Enhancement of photosensitivity in chemically deposited CdSe thin films by air annealing", J. Appl. Phys., vol. 74, pp. 1879-1884, 1993.

[55] S. Erat, H. Metin and M. Ar1, "Influence of the annealing in nitrogen atmosphere on the XRD, EDX, SEM and electrical properties of chemical bath deposited CdSe thin films", Mater. Chem. \& Phys., vol. 111, pp. 114-120, 2008.
[56] V.M. Garcia, M.T.S Nair, P.K. Nair and R.A. Zingaro, "Preparation of highly photosensitive CdSe thin films by a chemical bath deposition technique" Semicond. Sci .Tech., vol. 11, pp. 427, 1996.

[57] B.K. Rai, H.D. Bist, R.S. Katiyar, M.T.S. Nair, P.K. Nair, and A. Mannivannan, "Simultaneous observation of strong and weak quantum confinement effect in chemically deposited CdSe thin films: a spectro-structural study" J. Appl. Phys., vol. 82, pp. 1310-1319, 1997.

[58] Z. Loizos, N. Spyrellis and G. Maurin, "Electrochemical synthesis of semiconducting CdSe thin films" Thin Solid Films, vol. 204, pp. 139-149, 1991.

[59] A.V. Kokate, U.B. Suryavanshi and C.H. Bhosale, "Structural, compositional, and optical properties of electrochemically deposited stoichiometric CdSe thin films from non-aqueous bath”, Solar Energy, vol. 80, pp. 156-160, 2006.

[60] L.P. Colletti, B.H. Flowers and J.L. Stickney, "Formation of thin films of CdTe, CdSe, and CdS by electrochemical atomic layer epitaxy", Journal of the Electrochemical Society, vol. 145, pp. 1442-1449, 1998.

[61] S.J. Lade, M.D. Uplane, M.M. Uplane and C.D. Lokhande, "Structural, optical and photoelectrochemical properties of electrodeposited CdSe thin films", J. Mater. Sci: Mater. Electron, vol. 9, pp. 477-482, 1998.

[62] B. Su and K.L. Choy, "Electrostatic assisted aerosol jet deposition of CdS, CdSe and ZnS thin films", Thin Solid Films, vol. 361, pp.102-106, 2000.

[63] S. Velumani, X. Mathew, P.J. Sebastian, S.K. Narayandass and D. Mangalaraj, "Structural and optical properties of hot wall deposited CdSe thin films", Solar Energy Mater \& Solar Cells, vol. 76, pp. 347-358, 2003.

[64] S. Velumani, X. Mathew, P.J. Sebastian, S.K. Narayandass and D. Mangalaraj, "Thickness dependent properties of hot wall deposited CdSe films", Journal of Materials Science Letters, vol. 22, pp. 25-28, 2003.

[65] S. Velumani, S.K. Narayandass, D. Mangalaraj, P.J. Sebastian, $\mathrm{X}$. Mathew, "Dielectric and conduction studies on hot-wall deposited CdSe films", Solar energy materials and solar cells, vol. 81, pp.323-338, 2004.

[66] A.A. Yadav, M.A. Barote, E.U. Masumdar, "Studies on cadmium selenide (CdSe) thin films deposited by spray pyrolysis”, Mater. Chem. \& Phys., vol. 121, pp. 53-57, 2010.

[67] S. HyukáIm, and J. HyeokáPark, "CdS or CdSe decorated TiO2 nanotube arrays from spray pyrolysis deposition: use in photoelectrochemical cells", Chemical communications, vol. 46, pp. 2385-2387, 2010.

[68] J.L. Chin-hsin, and J.H. Wang, "Spray-Pyrolyzed Thin Film CdSe Photoelectrochemical Cells", Journal of The Electrochemical Society, vol. 129, pp.719-722, 1982.

[69] T. Elango, V. Subramanian, K.R. Murali, "Characteristics of spray-deposited CdSe thin films" Surface and Coatings Technology, vol. 123, pp. 8-11, 2000.

[70] F. Raoult, B. Fortin, A. Quemerais, G. Rosse, Y. Colin, "Influence of thermal treatments on the sensitivity of CdSe thin films to oxygen ionosorption", Journal of Physics and Chemistry of Solids, vol. 53, pp.723-732, 1992. 
[71] P.A. Nwofe, K.T.R. Reddy, G. Sreedevi, J.K. Tan, I. Forbes, R.W. Miles, "Single phase, large grain, p-conductivity-type SnS layers produced using the thermal evaporation method" Energy Procedia, vol.15, pp. 354-360, 2012.

[72] P.A. Nwofe, K.T.R. Reddy and R.W. Miles, "Influence of Deposition Time on the Properties of Highly-oriented SnS Thin Films Prepared Using the Thermal Evaporation Method" Advanced Materials Research, vol. 602, pp. 1409-1412, 2013.

[73] P.A. Nwofe, K.T.Ramakrishna Reddy and R.W. Miles "Type Conversion of $\mathrm{p}$-SnS to $\mathrm{n}$-SnS using a $\mathrm{SnCl}_{4} / \mathrm{CH}_{3} \mathrm{OH}$ heat treatment". IEEE Xplore Digital Library, 14115963, pp. 2518-2523, 2013.

[74] J. I. Pankove, "Optical Processes in Semiconductor, Prentice-Hall”, Upper Saddle River, New Jersey, p. 36, 1971.
[75] P.A. Nwofe, K.T.R Reddy, J.K. Tan, I. Forbes, and R.W. Miles, "Thickness dependent optical properties of thermally evaporated SnS thin films" Physics Procedia, vol. 25, pp. 150-157, 2012.

[76] P.A. Nwofe, K.T.R. Reddy, G. Sreedevi, J.K. Tan, R.W. Miles, "Structural, optical, and electro-optical properties of thermally evaporated tin sulphide layers" Japanese Journal of Applied Physics, vol.51, pp. 10NC36, 2012.

[77] A. Mondal, A. Dhar, S. Chaudhuri, A.K. Pal, Studies on photoelectrical, optical and galvanomagnetic properties of CdSe films. Journal of Materials Science, vol. 25, pp. 2221-2226, 1990. 